\title{
Higher Education Marketing Through Digital Community: Understanding the Motivations of Joining and Participating in University-Sponsored Communities and the Effect on Yield.
}

\author{
Evan C. Moore
}

Follow this and additional works at: https://researchrepository.wvu.edu/etd

\section{Recommended Citation}

Moore, Evan C., "Higher Education Marketing Through Digital Community: Understanding the Motivations of Joining and Participating in University-Sponsored Communities and the Effect on Yield." (2017). Graduate Theses, Dissertations, and Problem Reports. 8205.

https://researchrepository.wvu.edu/etd/8205

This Thesis is protected by copyright and/or related rights. It has been brought to you by the The Research Repository @ WVU with permission from the rights-holder(s). You are free to use this Thesis in any way that is permitted by the copyright and related rights legislation that applies to your use. For other uses you must obtain permission from the rights-holder(s) directly, unless additional rights are indicated by a Creative Commons license in the record and/ or on the work itself. This Thesis has been accepted for inclusion in WVU Graduate Theses, Dissertations, and Problem Reports collection by an authorized administrator of The Research Repository @ WVU. For more information, please contact researchrepository@mail.wvu.edu. 


\title{
Higher Education Marketing Through Digital Community: Understanding the Motivations of Joining and Participating in University-Sponsored Communities and the Effect on Yield
}

\author{
Evan C. Moore \\ Thesis submitted \\ to the Reed College of Media \\ at West Virginia University \\ in partial fulfillment of the requirements for the degree of \\ Master of Science in \\ Journalism
}

Geah N. Pressgrove, Ph.D., Chair

Julia D. Fraustino, Ph.D.

Mary Kay McFarland, M.A.

Jill R. Mosteller, Ph.D.

Department of Journalism

Morgantown, West Virginia

2017

Keywords: Digital Community, Social Media, University Recruitment, Admissions Copyright 2017 Evan C. Moore 


\begin{abstract}
Higher Education Marketing Through Digital Community: Understanding the Motivations of Joining and Participating in University-Sponsored Communities and the Effect on Yield
\end{abstract}

\author{
Evan C. Moore
}

As enrollment goals and student informational resources increase, universities are scrambling to be more competitive in the marketplace and implement more effective enrollment strategies. Digital closed online communities are one new method universities are using to reach students. Using an online survey, the authors investigated the motivations behind why students join these communities and how they participate in them. In addition, the research also tested how variables correlated to and predicted a student's behavioral intention to yield, or enroll at, the university. Findings expand Situational Theory of Problem Solving literature and establish connections between certain attributes and enrolling at the university. Specifically, students who had a clear plan to make their college decision, joined the closed online community, and reported more communicative action in the closed online community also reported a higher behavioral intention to enroll at the university associated with the app. 


\section{Table of Contents}

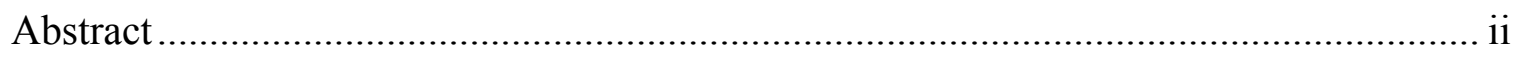

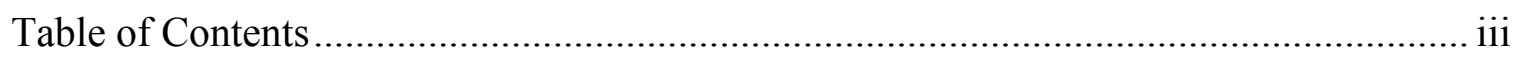

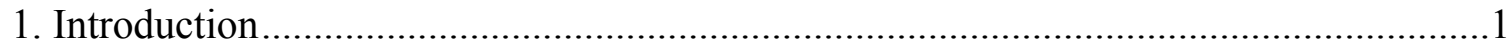

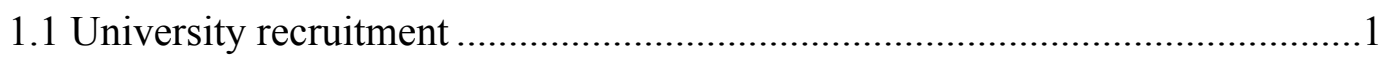

1.2 Social media in higher education recruitment .........................................2

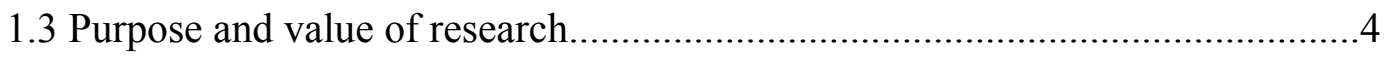

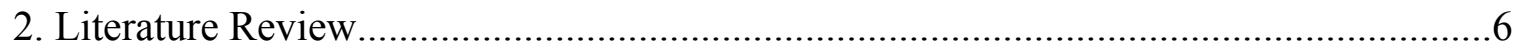

2.1 Situational Theory of Problem Solving (STOPS) .....................................

2.2 STOPS and behavioral intention to join a closed online community ..............9

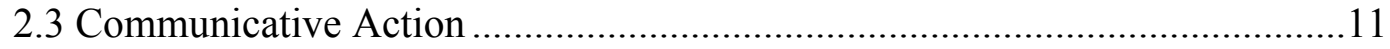

2.4 Communicative Action and behavioral intention to enroll...........................15

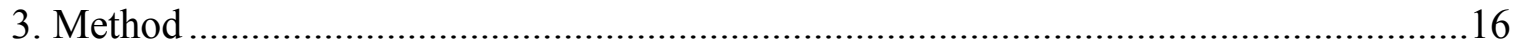

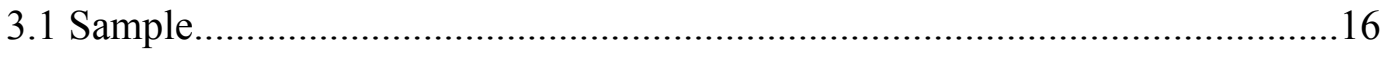

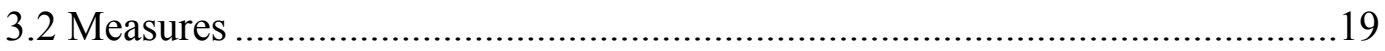

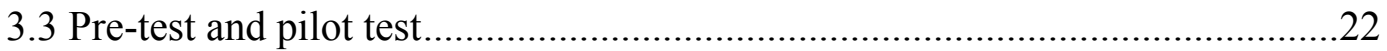

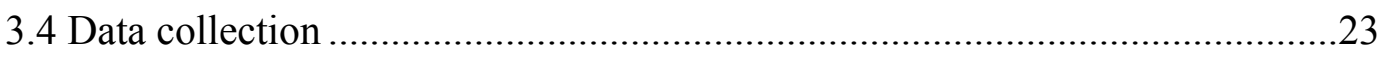

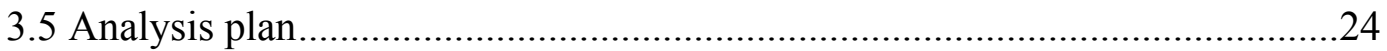

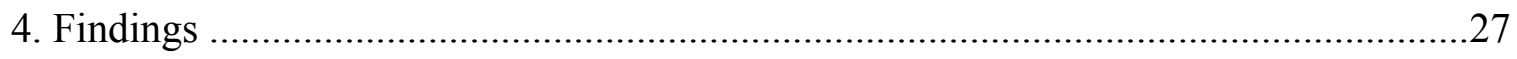

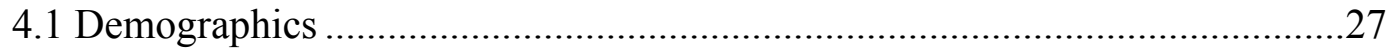

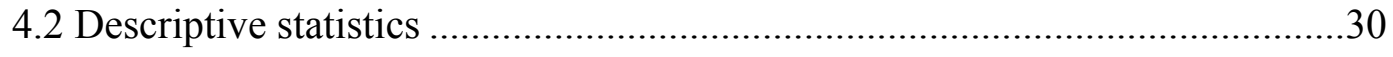

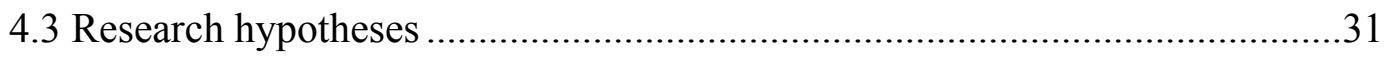

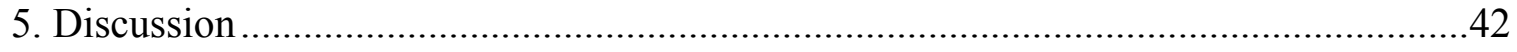




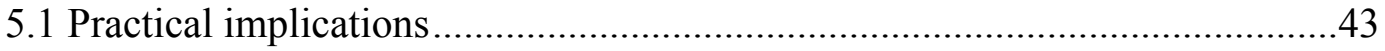

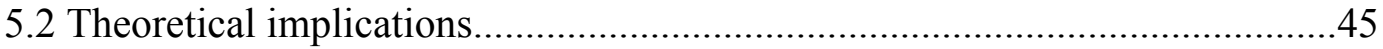

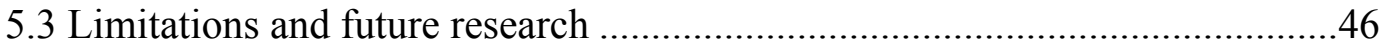

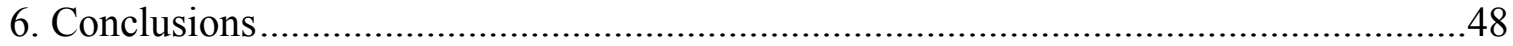

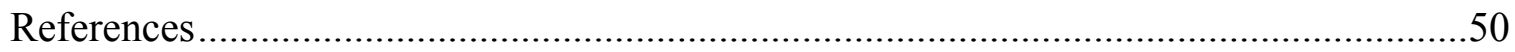

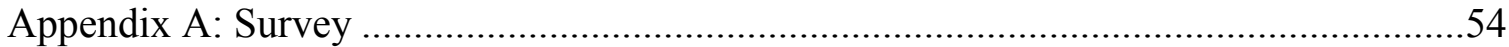




\section{Chapter 1: Introduction}

\subsection{University recruitment}

In recent years, institutions of higher education have entered a new era as external funding decreases and tuition dollars become more important to the school's bottom line. Net tuition, or "the amount of revenue an institution takes in from tuition and fees, net of all institutional grant aid," is responsible for 14 percent more of a student's education and related expenditures when comparing 2002-03 to 2012-13 (College Board, 2013). As a result, universities are relying heavily on student enrollment to fund institutional goals and efforts. The increase in the importance of net tuition revenue to the university is coupled with an average $\$ 1,390$ increase in inflation-adjusted tuition while government subsidies decreased per student by \$920 (College Board, 2013). Compounding the issues of increased cost for students and institutions, over 1,700 additional campuses have opened over the last 40 years dramatically increasing competition among institutions (Rhodes, 2006).

Although enrollment is becoming more important and competition is increasing among institutions, the number of prospective students is not dramatically changing. In fact, four-year institutions have seen student enrollment stagnate and higher education as a whole, including forprofit and two-year institutions, has seen a decrease in student enrollment (Ruffalo Noel-Levitz, 2015c). Universities cannot expect an increasing student population to take pressure off of enrollment challenges either. The total number of high school graduates, from both private and public schools, increased 27 percent between 1997 and 2010. The projected increase over the next 12 years is two percent (National Center for Education Statistics, 2014). According to the same study, enrollment at postsecondary institutions will increase by 14 percent over a similar 
period of time implying a challenging road ahead for institutions searching for more traditionally college-aged students.

As competition among universities increases and the student population stagnates, universities are searching for new ways to break through the noise and students are bombarded with more university information than ever before. The democratization of information gathering has contributed to the shifting landscape in higher education marketing, namely the advent of new media. Students have more tools, primarily online resources, compared to even a decade ago that assist in broadening the university search process (Ruffalo Noel-Levitz, 2015a). Students overwhelmingly cite institutional websites as the most important resource when researching universities and 60 percent of high schools seniors claim that they are "more likely to consider institutions that use email, text, and social media to communicate" compared to those using print brochures and phone calls (Ruffalo Noel-Levitz, 2015a, p. 4).

As the marketing landscape changes, institutions are still influenced by the historical reluctance to make brand marketing a top priority, but are also beginning to respond to the market forces that require a more aggressive marketing presence (Edmiston, 2008; Kirp, Berman, Holman, \& Roberts, 2003). At the same time, there is currently little significant academic literature for practitioners and researchers to use as they attempt to develop new and more effective strategies to inform and recruit students using computer-mediated strategies (Hemsley-Brown \& Oplatka, 2006).

\subsection{Social media in university recruitment}

Social media, defined as new generation internet applications that allow users to interact with others, communicate person-to-person, create user-generated content, and allow brands to interact with consumers, is a popular method of communication used by most Americans 
(Constantinides \& Stagno, 2012). Nearly two-thirds of adults now use some form of social media, and younger audiences are leading the way. In fact, 90 percent of young adults reported frequently using social media in 2015 compared to just 12 percent in 2005 (Perrin, 2015).

Social media has grown significantly in popularity as a search tool over the last decade as well. Only 21 percent of students reported that they had used social media to find information during their university search in 2011 (Ruffalo Noel-Levitz, 2015b). Just four years later, almost half of surveyed students indicated that they had used social media to research universities (Ruffalo Noel-Levitz, 2015b). While YouTube continues to be the most popular social media platform for students and many other platforms are making significant yearly gains in popularity, Facebook is regarded by students as the best platform to research universities (Ruffalo NoelLevitz, 2015a). As millennials embrace a social media-first mentality, universities have adjusted their strategies to meet their audience. One of these strategies is online community building for prospective students. While limited academic research exists demonstrating how universities are using community building, there is evidence to show that brands can benefit from communities that form on social media. For example, by increasing the dissemination of brand-related information and increasing the interactions consumers have with other consumers pertaining to the brand, brand marketers have seen an increase in the level of trust members of online communities have for the brand itself (Reza, Laroche, \& Richard, 2014).

One example of the use of social media community building in higher education is the adoption of private online communities such as the Schools App. The Schools App is a Facebook-like community for students used by over 100 universities to engage and enroll students through targeted communications and community building. Universities can customize the student experience in the app, such as what stage of the process students are invited to join, 
how much institutional messaging is included, and what kind of features students have access to (Martin, 2015). Within the app, students can interact with other future classmates, ask questions to university staff, and do so in a private environment. Students often use the Schools App to find more information about their college decision or to meet other incoming students after they have decided upon a specific college. Many universities have chosen to adopt tools like the Schools App instead of free solutions like Facebook Groups because of the increased control over membership in the community and access to additional tools that streamline workflow, such as the ability to receive email alerts after specific words or phrases are posted in the app. The Schools App integrates with admissions databases and the integration provides valuable student information for admissions professionals who interact with students on the social media platform. It can also be used to automatically evaluate a student's likelihood to enroll at the institution based on the quality of social interactions and other personal attributes.

While admissions professionals begin to leverage closed social networking apps with the intent to increase yield (when a student officially commits to a university) and institutional trust, little independent research has been published about the effectiveness of the tool and the student experience within it. Some early research, however, indicates a positive relationship between student retention, academic success, and participation in such apps (Fagioli, \& Rios-Aguilar, 2015).

\subsection{Purpose and value of research}

The purpose of this study is to better understand the reasons prospective students choose to join university-sponsored private online communities, the communicative actions they take within the communities, and how those actions might affect the decision to subsequently enroll at that university. As the higher education marketing landscape becomes more competitive and 
students have access to more information tools throughout their university search process, it is important to investigate how the students involved in private online communities are interacting within them and the effect their experiences are having on university enrollment outcomes.

The Situational Theory of Problem Solving (STOPS) will guide the investigation. STOPS provides a framework to better understand the factors that influence a student's decision to join a community by approaching the decision to join as an effort to solve a problem. In this case, the underlying problem for the student is finding the best information to assist in their decision to attend a university. As students join closed online communities, communicative action will be used to understand student communication and the effect that it may have on their university choice.

First, this study aims to better understand why students choose to voluntarily join online closed communities using the STOPS antecedent variables. Second, the study will investigate the types of communicative action students are likely to participate in within the online community to determine if there are correlations between motivated problem solvers and specific types of communication. Last, this study will investigate whether there is a correlation between a student's behavioral intention to attend the university, their problem solving motivations, and their intention to join an online closed community.

These findings should help shed light on how prospective students perceive and are using closed online communities to choose a university. With the rapid increase in the number of tools available to prospective students and the increase in importance of student enrollment to universities, this study will help fill a literature gap for practitioners hoping to leverage similar communities to meet enrollment goals. It will also expand STOPS literature into a new field and explore the theory in relation to behavioral intention. 


\section{Chapter 2: Literature Review}

\subsection{Situational Theory of Problem Solving}

The Situational Theory of Problem Solving (STOPS) is a method of understanding how and when people become agents of action after a discrepancy between their actual reality and their ideal reality is felt (Kim \& Grunig, 2011). STOPS is a generalized version of the foundational Situational Theory of Publics, often used to categorize publics within an organization or around an issue into groups (Kim \& Grunig, 2011; J.N. Kim, Ni, S.H. Kim \& J.R. Kim, 2012). Building on the Situational Theory of Publics, STOPS provides an extended framework in order to broaden the utility of the theory beyond application in the field of public relations and expand the definition of communicative action (J.N. Kim, Ni, S.H. Kim \& J.R. Kim, 2012).

Since Kim (2006) first proposed the theory in his seminal dissertation, STOPS has been applied to a variety of subjects. The theory has helped predict communicative activeness relating to hot-button issues like the War in Iraq and foreign meat imports (Kim, 2006; Kim \& Grunig, 2011; J.N. Kim, Ni, S.H. Kim \& J.R. Kim, 2012), organ donations (Kim, Shen \& Morgan, 2011), organ sales in developing countries (Kim \& Grunig, 2011), and the likelihood to express or withhold opinions in hostile social situations (Lee, Oshita, Oh \& Hove, 2014). These studies have consistently found that increased situational motivation in problem solving and the presence of referent criterion is a reliable predictor of increased communicative action, a problem solver's attempt at solving the problem through communication. The theory, however, has not yet been applied to predict communicative action in a marketing context or to examine the decisionmaking process for prospective college students. 
STOPS uses four antecedent variables. Problem recognition, involvement recognition, and constraint recognition are measured to assess one's situational motivation in problem solving, a dependent variable that leads to communicative action. Referent criteria is an independent variable that directly affects the communicative action a problem solver takes.

Problem recognition is defined by Grunig $(2003,2005)$ as a situation involving a dilemma that lacks an obvious solution. If there is no predetermined solution to the problem, the person enters into a problematic state and will alter their behaviors to find a solution. In other studies, problem recognition has been tested as the awareness of a shortage of organ donors (Kim, Shen \& Morgan, 2011) and the decision for South Korea to resume imports of foreign beef (J.N. Kim, Ni, S.H. Kim \& J.R. Kim, 2012). In the context of this study, the problematic situation is identified as the dilemma a prospective student encounters when they are presented with multiple institutions, all with their own advantages and disadvantages, to choose from. However, individuals might only alter their behaviors depending on their involvement recognition and constraint recognition.

Involvement recognition is a concept useful for analyzing one's relationship to an issue. Defined by Grunig (1997) as the degree a potential problem solver connects themselves to a situation, involvement recognition is considered a perceptual connection that may be independent from any actual connection (Grunig, 1976). Thus, a person may not take any action until they perceive a connection to a problem, regardless of real circumstance. Previous studies have defined involvement recognition as whether or not a person felt a connection to weight loss issues or the War in Iraq (Kim \& Grunig, 2011). In this study, involvement recognition will be defined as the relatedness a prospective student feels to the university decision they are presented with. For example, if a student feels that obtaining a degree from the right school is the only way 
to achieve their personal and professional goals, they may feel more involved with the problem: choosing the right school.

Constraint recognition occurs when a problem solver perceives obstacles impeding progress to a solution (Grunig, 1997). Constraints reduce the likelihood a person will take communicative action regardless of their problem recognition and involvement recognition (Ramanadhan \& Viswanath, 2006; Grunig, 1997; Kim \& Grunig, 2011). If a problem solver feels limited in the actions that are available to them, they will be discouraged to take action even when there is a felt need to do so. Constraint recognition has previously been operationalized as the sense of inability to impact large issues, such as the lack of organ donors (Kim, Shen \& Morgan, 2011), policy issues like affirmative action in higher education (Kim \& Grunig, 2011), or social issues like climate change (Lee, Oshita, Oh \& Hove, 2014). For this study, constraint recognition is the feeling that the high cost of education at one university is insurmountable or that their choice is predetermined, such as when a student follows in the footsteps of a long line of alumni from a specific institution. As a result, the student may be less likely to take communicative action to find a solution.

Problem recognition, involvement recognition, and constraint recognition are the exclusive antecedent variables for one's situational motivation in problem solving, a person's readiness to take communicative action in an effort to solve a problem (Kim \& Grunig, 2011). Communicative action is concurrently influenced by one's referent criterion.

Kim and Grunig (2011) define referent criterion as a problem solver's pre-existing experiences and knowledge pertaining to the problem at hand. For example, a first generation freshman student may report low referent criterion, while a transfer student who has been through the college admissions process before, may report high referent criterion. Problem 
solvers who have referent criteria may be less willing to search for more information to find a solution; however, there is evidence to suggest that they will take other communicative actions, such as sharing information, more (Grunig, 1968). Overall, recent findings suggest that the presence of referent criterion predicts an increase in communicative action (Kim, Shen \& Morgan, 2011; J.N. Kim, Ni, S.H. Kim \& J.R. Kim, 2012; Kim \& Grunig, 2011). These findings are particularly interesting when applying the use of referent criterion to a social situation, such as a closed online community. For the purpose of this study, referent criterion will be assessed as access to prior knowledge about the university search process, such as students who transfer from other institutions and have previously attended another university.

In sum, STOPS acknowledges that the four antecedent variables have independent and relative influence on one's communication behaviors depending on the situation. Three of the antecedent variables (problem recognition, involvement recognition, and constraint recognition) are summed up into a mediating variable of situational motivation in problem solving (Kim, 2006; Kim \& Grunig, 2011). It combines the three antecedent variables into one useable measurement of a problem solver's overall readiness to take communicative action. If one's situational motivation in problem solving is high, it is likely they will participate in communicative action to remedy their problem. In addition, their referent criterion will positively influence those communicative actions.

\subsection{STOPS and behavioral intention to join a closed online community}

The authors will employ behavioral intention, a variable in the Theory of Planned Behavior, to better understand how students' behaviors are affected by their motivations and communicative actions. The Theory of Planned Behavior, developed by Azjen $(1985,1991)$ as a more predictive model of the Theory of Reasoned Action (Azjen \& Fishbein, 1980; Fishbein \& 
Azjen, 1975), explains that a person's attitudes, subjective norms, and perceived behavioral control influence one's behavioral intentions which result in actual behavior. Behavioral intentions are used to illustrate one's likelihood to act in relation to an issue (Azjen, 1991). Armitage \& Conner (2001) conducted a meta-analysis of 185 independent studies using the Theory of Planned Behavior and concluded that behavioral intention has been reliably used to predict behaviors in a number of fields and studies.

While the theory was not intended to link to non-communicative behaviors, STOPS has been applied to a person's behavioral intentions in addition to their communicative action (Grunig, 1997; Kim, Shen \& Morgan, 2011). Kim, Shen, and Morgan (2011) investigated organ donation issues and found the expected correlation between one's situational motivation in problem solving and their likelihood to take communicative action, but, interestingly, they found that a high situational motivation also predicted their likelihood to be an organ donor. The same study was not able to support a hypothesis that referent criterion predicted behavioral intentions. This is important to the topic of research because it shows a possible link between a person's awareness of a problematic situation and their non-communicative behaviors such as student yield, the intent to attend a university after admission.

The closed online community in this study is a communicative experience that admitted students are invited to but not required to participate in. The community is marketed as a place where students can ask questions, interact with other students, and have access to timely announcements and resources. Based on the fact that previous research indicates communicative and non-communicative behavioral intentions are linked to STOPS antecedents, we propose the following hypothesis: 
RH1: Problem recognition (RH1a), involvement recognition (RH1b), constraint recognition (RHIc), and referent criterion (RHId) predict intention to join a closed online community.

For the purposes of this study, problem recognition, involvement recognition, and constraint recognition will be combined and measured as situational motivation in problem solving instead of as individual variables. Following the example of previous studies, the remainder of the analysis will approach these STOPS variables only in terms of the merged situational motivation in problem solving.

\subsection{Communicative Action}

Communication is inherently linked to problem solving, and communicative action helps explain the behaviors that problem solvers use to find solutions. Reconceptualized by Kim, Grunig, and $\mathrm{Ni}$ (2010) to address a lack of literature pertaining to behaviors outside of information acquisition ( $\mathrm{Ni}$ and Kim, 2009), communicative action acts as a dependent variable of situational motivation in problem solving and referent criterion. Simply put, STOPS explains that as one's situational motivation in problem solving increases and referent criteria exist, the likelihood a problem solver will participate in communicative action will increase (Kim \& Grunig, 2011). The strength of the reconceptualization is that it allows for a broader understanding of the varied communicative behaviors that an individual takes part in. This is particularly useful when considering actions related to social media, a medium that inherently relies on publics to be active participants in information use and is increasingly used as an informational tool in the university search process (Ruffalo Noel-Levitz, 2015a). 
Kim, Grunig, and Ni’s (2009) communicative action model is divided into three primary actions: information selecting, information transmitting, and information acquiring. These actions are further divided into two sub-dimensions according to whether the action is active or passive creating a total of six dependent variables: information forefending (active), information permitting (passive), information forwarding (active), information sharing (passive), information seeking (active), and information attending (passive).

Information seeking and information attending, the original variables from the situational theory of publics (Grunig, 1997), represent the function of acquiring information. Information seeking is the active process of searching for information and information attending is passive. Information seeking is typically the first communicative action motivated problem solvers take and describes the process of intentionally searching for information related to the problem (Kim \& Grunig, 2011). In contrast, information attending describes the passive discovery of information in the environment without prior intent and does not include a calculated search for information. In the context of this study, information seeking is identified as proactively searching for information about the university within the online community and information attending is identified as obtaining information that, while possibly important to a student's decision, was not purposefully sought after while in the closed community. With the knowledge that motivated problem solvers are more likely to acquire applicable information (Kim \& Grunig, 2011) and prospective college students are actively participating in a variety of methods to learn about universities (Ruffalo Noel-Levitz, 2015b), we propose the following hypotheses:

RH2: Situational motivation in problem solving (RH2a) and referent criterion (RH2b) are positively related to information seeking. 
RH3: Situational motivation in problem solving (RH3a) and referent criterion (RH3b) are positively related to information attending.

Information forefending and information permitting demonstrate how a problem solver interprets and selects available information (Kim \& Grunig, 2011). Information forefending is an active process of information selecting while information permitting is a passive process. A problem solver that exhibits high levels of information forefending is strategically thinking through the problem to reduce the amount of noise, or irrelevant information, that may distract from a solution (Kim, Grunig \& Ni, 2010). Problem solvers with referent criteria typically exhibit a higher level of information forefending as they approach the problem with prior experience and information. Those who are highly motivated to solve a problem, but do not have referent criteria tend to be particularly permitting as they attempt to build a knowledge base. This group can be difficult to communicate with because, as explained by Kim, Grunig and Ni (2010), "they cannot competently distinguish applicable information from that which is simply available" (p. 138). In both cases, however, situational motivation and referent criteria have been associated with higher levels of forefending and permitting. In the context of this study, information forefending is identified as actively participating in specific conversation threads that adhere to the student's interests and information permitting is identified as a willingness to absorb information that may not be directly applicable to a student's current interests. Thus, we propose the following hypotheses:

RH4: Situational motivation in problem solving (RH4a) and referent criterion (RH4b) are positively related to information forefending. 
RH5: Situational motivation in problem solving (RH5a) and referent criterion (RH5b) are positively related to information permitting.

Information forwarding and information sharing are the two actions a problem solver takes when participating in information transmission, the process of conveying information to activate other problem solvers' knowledge about and perceptions of the problem (Kim \& Grunig, 2010; McLeod \& Chaffee, 1973). Information forwarding is the active method of transmission and information sharing is passive. As explained by Kim \& Grunig (2010), information forwarding is defined as transmitting information whether it was solicited or not. The act of information forwarding is purposeful and planned with the intention of relaying the preferred solution to others faced with a similar problem. Information sharing occurs when a problem solver's opinion is requested by another facing the same issue, but is not voluntarily produced; a passive approach to transmission. Social media provides the ideal environment for information transmission and, as seen in social media and private online communities (Fagioli, Constantinides \& Stagno, 2012; Martin, 2015; Ruffalo Noel-Levitz, 2015a; Fagioli \& RiosAguilar, n.d.), prospective students often rely on each other proactively and reactively for information relating to choosing the right university. In the context of this study, information forwarding is identified as proactively answering questions from other students and expressing opinions in the online community while information sharing is identified as expressing an opinion or experience when prompted by another member of the community. Based on the findings above, we propose the following hypotheses: 
RH6: Situational motivation in problem solving (RH6a) and referent criterion (RH6b) are positively related to information forwarding.

RH7: Situational motivation in problem solving (RH7a) and referent criterion ( $R H 7 b)$ are positively related to information sharing.

\subsection{Communicative Action and behavioral intention to enroll}

As evidenced by previous research, a relationship may exist between situational motivation, referent criterion, and the communicative actions that result to one's behavioral intentions (Kim, Shen \& Morgan, 2012). If the problem students face is to find the best university, those who are situationally motivated, join available closed online communities, and engage in communicative action may also be more motivated to attend the university in question. Thus, the following research hypotheses are proposed:

RH8: Situational motivation in problem solving (RH8a) and referent criterion (RH8b) are positively related to the behavioral intention of enrolling at the university.

RH9: Information seeking (RH9a), information attending (RH9b), information forefending (RH9c), information permitting (RH9d), information forwarding (RH9e), and information sharing (RH9f) are positively related to the behavioral intention of enrolling at the university.

RH10: Joining an online community is positively related to the behavioral intention of enrolling at the university. 


\section{Chapter 3: Method}

To better understand the problem solving motivations, communicative behaviors, and behavioral intentions of prospective university students, the authors surveyed a group of students admitted to a western, four-year public university who joined a closed online community. The university has employed the use of a specific closed online community, the Schools App, for three years and allows students to voluntarily join the app following admission. After students voluntarily join the app, they can take part in a variety of communicative behaviors. The university and the proprietor of the app send a variety of marketing communications encouraging the students to join the app, which suggests that most admitted students are familiar with the product.

\subsection{Sample}

Because university student bodies consist of varying degrees of demographic diversity and social media participation can be skewed according to demographics (Duggan, M., 2015), it is important to create a representative sample of the admitted student population from the western, four-year public university participating in the study. As a result, proportionate stratified random sampling was used to survey students. According to Zhou and Sloan (2011), proportionate stratified random samples are particularly useful when researchers have access to the whole population and wish to ensure that subgroups within the population are represented accurately. By using a proportionate stratified random sample, the authors were able to control for basic demographic information and ensure the sample was characteristic of the expected population of admitted students at the university. In addition, sampling a subset of the population helped reduce a possible impact from the study on the entire population's behavior while still surveying a demographically representative group. 
The authors surveyed a total of 5,000 students evenly distributed between students who joined the closed online community and those who did not join the closed online community. However, for the purposes of this study the authors will only analyze data from respondents who joined the app. This study is the first phase in a multi-phase study and will serve as the foundation for future analysis. The scope of this study has been limited to joiners and only data from the group that has joined the closed online community will be discussed for the remainder of the study.

Of the 2,500 students who were confirmed as joiners, 502 responded to and completed the survey, a response rate of $20 \%$. The authors controlled for student residency (in-state, out-ofstate student), student type (traditional freshman, transfer student), gender (female, male, not reported), race (Asian, Black, Native, Hawaiian/Pacific-Islander, White, two or more races, not reported), ethnicity (Hispanic, non-Hispanic), and citizenship (U.S. citizen, international student) according to the total admitted student population from the previous year at the same university. For example, the sample consisted of $41 \%$ male and $59 \%$ female respondents in an attempt to mirror the gender distribution from the previous year's admitted population: $45 \%$ male and 55\% female (see full demographics in Table 1). In doing so, the authors are able to ensure that the sample more accurately represents the expected admitted student population at the university involved in the study even though the survey was sent before the entire population developed. Student applications at the university are accepted and processed several months after the deployment of this survey, which necessitated such an approach. In addition, it was important to survey the population in the early spring because waiting may have negatively impacted the response rate as students often select their final university during the spring. 
Table 1:

Demographic Characteristics for Fall 2016 Admitted Students Eligible to Join the Closed Online Community at the University and Full Research Sample

\begin{tabular}{|c|c|c|c|c|}
\hline Demographic characteristic & $\begin{array}{l}\text { Fall } 2016 \\
\text { population }\end{array}$ & $\begin{array}{l}\text { Fall } 2016 \% \text { of } \\
\text { total population }\end{array}$ & $\begin{array}{l}\text { Number in } \\
\text { sample solicited }\end{array}$ & $\begin{array}{l}\% \text { of total in } \\
\text { sample solicited }\end{array}$ \\
\hline \multicolumn{5}{|l|}{ Student residency } \\
\hline In-state & 9,296 & $47 \%$ & 2,352 & $47 \%$ \\
\hline Out-of-state & 10,341 & $53 \%$ & 2,648 & $53 \%$ \\
\hline \multicolumn{5}{|l|}{ Student Type } \\
\hline Freshman & 16,963 & $86 \%$ & 4200 & $84 \%$ \\
\hline Transfer & 2,674 & $14 \%$ & 800 & $16 \%$ \\
\hline \multicolumn{5}{|l|}{ Gender } \\
\hline Male & 8,774 & $45 \%$ & 2047 & $41 \%$ \\
\hline Female & 10,843 & $55 \%$ & 2940 & $59 \%$ \\
\hline Not Reported & 20 & $0.1 \%$ & 11 & $0 \%$ \\
\hline \multicolumn{5}{|l|}{ Ethnicity } \\
\hline Hispanic & 2,815 & $14 \%$ & 730 & $15 \%$ \\
\hline Non-Hispanic & 15,946 & $81 \%$ & 4042 & $81 \%$ \\
\hline \multicolumn{5}{|l|}{ Race (Non-Hispanic) } \\
\hline Asian & 907 & $5 \%$ & 277 & $6 \%$ \\
\hline Black & 552 & $3 \%$ & 157 & $3 \%$ \\
\hline Native & 96 & $0 \%$ & 69 & $1 \%$ \\
\hline Hawaiian/Pacific-Islander & 46 & $0 \%$ & 29 & $0.6 \%$ \\
\hline White & 13,409 & $68 \%$ & 3685 & $74 \%$ \\
\hline Two or more races & 840 & $4 \%$ & 211 & $4 \%$ \\
\hline Not reported & 96 & $0 \%$ & 54 & $1 \%$ \\
\hline \multicolumn{5}{|l|}{ Citizenship } \\
\hline Domestic (U.S.A. citizen) & 18,701 & $95 \%$ & 4772 & $95 \%$ \\
\hline International (Foreign National) & 936 & $5 \%$ & 228 & $5 \%$ \\
\hline
\end{tabular}




\subsection{Measures}

The authors of this study employed a questionnaire with validated measures based on previous studies using STOPS, communicative action, and behavioral intention with minor modifications to make measurements applicable to the topic (Kim, 2006; Kim \& Grunig, 2011; Pressgrove \& McKeever, 2016). Respondents rated their level of agreement with each statement on a five-point Likert-scale to allow for quick completion of the survey and quick analysis of the data by the authors (Zhou \& Sloan, 2011). The scale measured responses from "strongly disagree" to "strongly agree." The survey was broken into four sections related to a specific measurement, each introduced by a short paragraph to ensure students responded to the questions in the correct context. No contextual information about the respondent was collected due to the authors' ability to match accurate demographic information to a student's responses while maintaining confidentiality. A full version of the questionnaire can be found in Appendix A.

STOPS measures were initially developed and validated by Kim (2006) who used Grunig's (1976) Situational Theory of Publics as a model for constraint recognition, involvement recognition, information seeking, and information attending. Measures for STOPS include four antecedent variables (problem recognition, involvement recognition, constraint recognition, and referent criterion) and situational motivation in problem solving. These measures refer to a student's university "decision" which is defined at the beginning of the questionnaire as a student's "experiences thinking about different universities."

Students were prompted to respond to four measures for each of the following variables. The first variable measured was problem recognition ("I am very concerned about this," "I consider this decision seriously," "I believe I need to pay more attention to this decision," "I see a huge gap between where I am and where I want to be with the decision"). The second variable 
measured was constraint recognition ("I am not afraid to take action related this decision," "I can make difference the way this decision solved," "I can improve the situation by taking action related this decision," "I find no obstacles in making this decision"). The third variable measured was involvement recognition ("This decision affects my life," "I think this decision could affect me personally," "I am connected with this decision and its consequences," "This decision has serious consequences for my life"). The fourth variable to be measured is referent criterion ("I know how to deal with this decision," "I have a clear idea and direction to deal with this decision," "I have faced a similar decision in the past," "This decision makes me more emotional than the other decisions I have experienced in the past”). Situational motivation in problem solving was also measured to serve as a cumulative measure of problem, involvement, and constraint recognitions ("I am curious about this decision," "I frequently think about this decision," "I would like to better understand this decision," "I often stop and think about this decision").

Measures for communicative action are based off of updated, two-item scales presented by McKeever, McKeever, Holton, \& Li (2016). Measures for communicative action include six sub-variables divided into an active group (information forefending, information forwarding, information seeking) and a passive group (information permitting, information sharing, information attending) (Kim \& Grunig, 2011). Students were prompted to respond to two measures for each of the following variables related to their communicative experience in the online app. The active group was measured with information forefending ("I have invested enough time and energy to inform myself about [the university]," "I know where to go when I need updated information regarding [the university]"), information forwarding ("I enjoy opportunities to educate others with information about [the university]," "I forward information 
about [the university] to people I know"), and information seeking ("I search for information about [the university] in the news or online," "I actively search for information about [the university]"). The passive group was measured with information permitting ("I want to know about [the university] from multiple sources," "I welcome any information about [the university] "), information sharing ("I would be willing to talk to someone about [the university] if they asked me," "I may not initiate but I am willing to have a conversation about [the university]"), and information attending ("If I hear someone talking about [the university], I am likely to listen," "If I see something about [the university] in the news or online, I am likely to watch/listen/read the story").

The survey included questions intended to gauge a student's behavioral intent to join and participate in the closed online community. This measure is important because, even though this study concentrates only on students who have joined the closed online community, data was gathered from students who did not join the community as well. Students were prompted to respond to four measures related to their intent to join the closed online community ("If there was a way to meet other prospective students, I would participate," "I am likely to take part in social media communities with other prospective students," "I plan to join the closed online admitted student community at [the university] (the Schools App)," "I am not interested in participating in online communities with other prospective students"). Last, students were asked if they joined the app to compare their answers to the record from the app ("Have you joined the Schools App?").

Students were also prompted to respond to four measures to assess their behavioral intent to enroll at the university ("I intend to enroll at [the university] in the fall," "[the university] is one of my top schools," "I plan to go to a different university or institution than [the university]," 
"If there were no limiting factors (e.g., cost, distance, etc.) I would attend [the university] in the fall”). Following those questions, students were prompted to answer two more questions about their experience applying to and being admitted to other universities ("I applied to universities or institutions other than [the university]," "I was admitted to universities or institutions other than [the university],"). If students answered "yes" to either of those questions, an open-ended field prompted them to answer how many other universities they applied to or were admitted to.

\subsection{Pre-test and pilot test}

In order to identify possible issues with the measurement tools, a pre-test and pilot test were employed before the survey was sent to any respondents included in the data analysis. Pretests are used to identify possible issues with the survey instrument such as poorly designed questions or content (Zhou \& Sloan, 2011). First, the pre-test was sent to a small group of four employees in the Office of Admissions at the university familiar with the closed online community. The employees were given an opportunity to take survey and provide feedback through email related to their experience. Minor wording and organizational changes were made based on the feedback to improve the clarity of some questions and correct errors within the instrument.

The pilot test was then sent to a group of 45 current university students via email also familiar with the closed online community. Due to a low response rate from the initial group of current students, 100 prospective students were chosen at random from the admitted student pool and sent the survey via email five days later to increase the total number of respondents. The results from the 35 total respondents were then cleaned and analyzed to ensure data was gathered in full and errors had been corrected in the survey instrument. The pilot test was also used to gauge the typical amount of time needed to complete the survey. 


\subsection{Data collection}

Each student who applies to the university must do so using an email address and must complete an extensive online application. Knowing that all applicants are already in contact via email with the university, the authors sent an online questionnaire using Qualtrics software to the sample population. An online survey, defined by Zhou and Sloan (2011) as a "method to poll respondents for their opinions, attitudes, and behaviors," was used as the method of inquiry in this study because it allowed the authors to reach a large number of students at low cost.

The survey was sent to the sample of admitted students in mid-February 2017 when the university historically has already received and processed the majority of applicants for the upcoming academic year. An email containing a link to the survey was sent from the Office of Admissions at the university, an office that has likely been in communication with admitted students for an extended period of time and is a trusted source of information. To increase the response rate, the email notified students that a box of promotional school spirit items would be sent to one respondent at random following the conclusion of the survey. Due to an acceptable response rate, no follow-up messages or additional incentives were needed.

Since the sample had already applied to the university and demographic information is collected as part of that process, no questions about the students' demographic characteristics were included in the survey. The authors worked with employees at the university to match respondents' demographic information received through their application to their respective answers. To achieve confidentiality, the student's contact information was loaded into Qualtrics, the survey was deployed, and the student's demographic information was added to the survey after it was closed. Then, all identifiable information was removed and the results were returned 
to the authors for analysis. Last, to guarantee anonymity during data analysis, all data has been reported in the aggregate.

The process above ensures accurate demographic information, considerably shortened the survey, and maintained confidentiality for all respondents. Demographic and student information matched to student responses includes: race (no response, Asian, Black, Pacific/HawaiianIslander, Native, White, Multi-Racial), Hispanic (yes, no), sex (self-identify, male, female), student type (second bachelor's, freshman, transfer), first generation status (yes, no), residency (in-state resident, non-resident, not determined), most recent decision on record (admit, deposit deferral denied, deposit deferred, deposit not required, deposit paid, deposit pending, regret, withdrawal), citizenship (U.S. citizen, permanent resident, foreign national, dual citizen), calculated high school GPA, combined college GPA, ACT superscore, SAT superscore.

The authors also matched participation data from the closed online community to each respondent's survey answers. Using the same process employed to match demographic information, the authors confidentially combined data taken from the app to the data received from the survey. Participation data from the Schools App includes: join status (yes, no), number of conversations started or joined, number of friends in the Schools App, number of Facebook friends that have also joined the Schools App, inbound conversation starters, and number of communities joined. This data adds confidence in the respondents' behavioral intention data pertaining to app usage and provides context to their activeness in the app.

\subsection{Analysis}

Data was gathered in Qualtrics using the procedures outlined above and was downloaded into SPSS. Before analyzing the data using the statistical tests in Table 2, the data was cleaned and descriptive statistics were reported. While reviewing the descriptive statistics (means, 
frequencies, standard deviation, skewness, kurtosis), the authors noticed that data was heavily skewed and did not exhibit a normal distribution. The authors then used Cronbach's Alpha to assess the reliability of the measures and found that most variables did not exhibit an acceptable internal reliability.

The Situational Theory of Publics, the foundation of the Situational Theory of Problem Solving, has received scrutiny in the past for exhibiting low alphas which has been related to the difficulty in choosing proper measures for variables; however, its potential for use in untested fields is also stressed (Grunig, 2006; Aldoory \& Sha, 2007). Relating the college decision to the Situational Theory of Publics is a new and, until now, an untested use of the measures. Due to the emotional and serious nature of the decision, the authors believe responses from the prospective students may have been skewed. For example, much of the previous STOPS research has concentrated on social topics such as weight loss and affirmative action that, while still serious in nature, may not be as personal or impactful for all members of the sample.

As a result, the authors approached reliability in a manner that focused on assuring the measures used reflected the original intent of the STOPS variables as developed (Grunig \& Hunt, 1984) and the inclusion of referent criterion (Sha, 2006). First, the authors calculated the interitem correlations for the variables and removed the two measures from the four-measure variables that exhibited the lowest inter-item correlation. Before proceeding the authors reviewed the seminal work in the STOPS literature to assure that the face value of the two measures accurately represented the intended operationalization of the variable. The authors then tested for internal reliability using Pearson's $r$. Correlations and alphas are reported in Table 6 . The statistical tests used to analyze the data are reported in full in Table 2. 
Table 2

Statistical analyses used for research hypotheses

Research hypotheses

Statistical test

RH1: Problem recognition (RH1a), involvement recognition (RH1b), constraint recognition (RH1c), and referent criterion (RH1d) predict intention to join a closed online community.

RH2: Situational motivation in problem solving (RH2a) and referent criterion (RH2b) are positively related to information seeking.

RH3: Situational motivation in problem solving (RH3a) and referent criterion (RH3b) are positively related to information attending.

RH4: Situational motivation in problem solving (RH4a) and referent criterion (RH4b) are positively related to information forefending.

RH5: Situational motivation in problem solving (RH5a) and referent criterion (RH5b) are positively related to information permitting.

RH6: Situational motivation in problem solving (RH6a) and referent criterion (RH6b) are positively related to information forwarding.

RH7: Situational motivation in problem solving (RH7a) and referent criterion (RH7b) are positively related to information sharing.

RH8: Situational motivation in problem solving (RH8a) and referent criterion (RH8b) are positively related to the behavioral intention of enrolling at the university.

RH9: Information seeking (RH9a), information attending (RH9b), information forefending (RH9c), information permitting (RH9d), information forwarding (RH9e), and information sharing (RH9f) are positively related to the behavioral intention of enrolling at the university.

RH10: Joining an online community is positively related to the behavioral intention of enrolling at the university.

Pearson's $r$

Multiple regression

Pearson's $r$

Multiple regression

Pearson's $r$

Multiple regression

Pearson's $r$

Multiple regression

Pearson's $r$

Multiple regression

Pearson's $r$

Multiple regression

Pearson's $r$

Multiple regression

Pearson's $r$

Multiple regression

Pearson's $r$

Multiple regression

Pearson's $r$ 


\section{Chapter 4: Findings}

\subsection{Demographics}

As previously discussed, 502 students responded out of the subset of the 2,500 students who joined the Schools App and received the survey. As seen in Table 3, 69\% of respondents were female, $31 \%$ were male, and $0.2 \%$ self-identified. Most students identified as white ( $84 \%)$, while the second most popular group identified as multi-racial (5\%). A separate question asked whether students identified as Hispanic, and $17 \%$ of respondents did. In addition, $94 \%$ of respondents are solely United States citizens, $2 \%$ of students have dual citizenship (U.S. included), and 4\% are not United States citizens. A complete report of respondent's race, gender, and citizenship can be found in Table 3.

The authors also received access to respondents' academic status and other academic information. Considering student type, most respondents were freshmen (90\%), and less than one-tenth were transfer students $(10 \%)$. Also, more than half $(53 \%)$ of respondents were nonresidents of the state where the university is located. Over half of respondents had already paid or deferred their enrollment deposit (62\%) indicating that most of the respondents are likely to yield at the university. Over one-third of the respondents (36\%) had taken no action at all concerning their enrollment status and only two respondents $(0.4 \%)$ had notified the university that they were not planning on attending college at the university. A complete report of respondent's student type, first generation status, in-state residency, and enrollment status can be found in Table 4. 
Table 3

Demographic Descriptive Statistics from Respondents

\begin{tabular}{|c|c|c|}
\hline & $\mathrm{N}$ & $\%$ \\
\hline \multicolumn{3}{|l|}{ Race } \\
\hline Asian & 17 & $3 \%$ \\
\hline Black & 15 & $3 \%$ \\
\hline Hawaiian/Pacific-Islander & 1 & $0.2 \%$ \\
\hline Native American & 1 & $0.2 \%$ \\
\hline White & 420 & $84 \%$ \\
\hline Multi-racial & 25 & $5 \%$ \\
\hline No response & 23 & $5 \%$ \\
\hline \multicolumn{3}{|l|}{ Hispanic } \\
\hline Yes & 87 & $17 \%$ \\
\hline No & 415 & $83 \%$ \\
\hline \multicolumn{3}{|l|}{ Gender } \\
\hline Male & 152 & $31 \%$ \\
\hline Female & 348 & $69 \%$ \\
\hline Self-identify & 1 & $0.2 \%$ \\
\hline \multicolumn{3}{|l|}{ Citizenship } \\
\hline U.S. Citizen & 469 & $93 \%$ \\
\hline Permanent Resident & 5 & $1 \%$ \\
\hline Foreign National & 17 & $3 \%$ \\
\hline Dual Citizenship (U.S.) & 11 & $2 \%$ \\
\hline
\end{tabular}


Table 4 Academic-related Descriptive Statistics for Respondents

\begin{tabular}{lcc}
\hline \multicolumn{1}{l}{ N } & $\%$ \\
\hline Student Type & & \\
Freshman & 453 & $90 \%$ \\
Transfer & 49 & $10 \%$ \\
First Generation & & \\
Yes & 117 & $23 \%$ \\
No & 385 & $77 \%$ \\
In-state Residency & & \\
Yes & 234 & $47 \%$ \\
No & 268 & $53 \%$ \\
Enrollment Status at the Time of & & \\
Survey & & \\
Admit (not deposited) & 182 & $36 \%$ \\
Deposit Deferred & 70 & $14 \%$ \\
Deposit Paid & 240 & $48 \%$ \\
Deposit Pending & & \\
Regret & & \\
\hline
\end{tabular}

The authors also combined available participation data from the closed online community with respondents' records. Most respondents (59\%) have not been involved in a conversation in the app; however, almost $5 \%$ of respondents were involved in over 10 conversations.

Interestingly, over three-fourths of respondents $(77 \%)$ had joined at least one community, with most students (72\%) joining up to five communities. A complete report of student participation in the Schools App, including the number of friends in the app, number of conversations started or joined, and the number of communities joined can be found in Table 5. 
Table 5

Schools App Participation Descriptive Statistics for Respondents

\begin{tabular}{lcc}
\hline & $\mathrm{N}$ & $\%$ \\
\hline Friends in Schools App & 204 & $41 \%$ \\
0 & 186 & $37 \%$ \\
$1-5$ & 87 & $17 \%$ \\
$6-10$ & 25 & $5 \%$ \\
$11+$ & & \\
Conversations Started or Joined & 298 & $59 \%$ \\
0 & 135 & $27 \%$ \\
$1-5$ & 30 & $6 \%$ \\
$6-10$ & 39 & $8 \%$ \\
$11+$ & & \\
Communities Joined & & \\
0 & 114 & $23 \%$ \\
$1-5$ & 359 & $72 \%$ \\
\hline 10 & 7 & $1 \%$ \\
\hline
\end{tabular}

\subsection{Descriptive statistics}

Table 6 includes correlation values between indicators for each measure, Cronbach's Alpha for behavioral intention measures, means, standard deviation and skewness for all variables. All means are above the midpoint of the scale with only one variable, problem recognition $(M=2.89)$, below three. In fact, most variables are skewed (7 out of 13) beyond negative one, which has been previously discussed in the methodology.

Table 6

Descriptive Statistics 


\begin{tabular}{|c|c|c|c|}
\hline Variable & Mean & $S D$ & Skewness \\
\hline \multicolumn{4}{|l|}{ STOPS Variables } \\
\hline Problem Recognition $\left(r=.33^{*}\right)$ & 2.89 & 1.06 & -.09 \\
\hline Constraint Recognition $\left(r=.30^{*}\right)$ & 3.43 & .96 & -.20 \\
\hline Involvement Recognition $\left(r=.35^{*}\right)$ & 4.17 & .85 & -1.05 \\
\hline Referent Criterion $\left(r=.56^{*}\right)$ & 3.90 & .93 & -.76 \\
\hline $\begin{array}{l}\text { Situational Motivation in Problem Solving } \\
\left(r=.53^{*}\right)\end{array}$ & 4.31 & .81 & -1.38 \\
\hline \multicolumn{4}{|l|}{ Behavioral Intention } \\
\hline Schools App $(\alpha=.77)$ & 4.39 & .62 & -1.28 \\
\hline Attend the University $(\alpha=.72)$ & 4.45 & .57 & -1.18 \\
\hline \multicolumn{4}{|l|}{ Communicative Action } \\
\hline Information Forefending $\left(r=.39^{*}\right)$ & 4.19 & .78 & -.94 \\
\hline Information Permitting $\left(r=.45^{*}\right)$ & 4.57 & .57 & -1.69 \\
\hline Information Forwarding $\left(r=.57^{*}\right)$ & 3.69 & 1.00 & -.47 \\
\hline Information Sharing $\left(r=.25^{*}\right)$ & 4.50 & .59 & -1.34 \\
\hline Information Seeking $(r=.61 *)$ & 4.00 & .93 & -.80 \\
\hline Information Attending $\left(r=.57^{*}\right)$ & 4.65 & .55 & -2.20 \\
\hline
\end{tabular}

Note $* p<.001$.

\subsection{Research Hypotheses}

STOPS variables and their relationship to behavioral intention to join a closed online community

According to previous research, STOPS antecedent variables predict higher communicative action and also may predict behavioral intention. The first research hypothesis suggests that STOPS antecedent variables would be positively related with a student's behavioral intention to join the closed online community. As seen in Table 7, RH1 a-d is partially 
supported. Both constraint recognition $r=.31(p<.01)$ and referent criterion $r=.32(p<.01)$ have a significant positive relationship to intention to join the Schools App. However, results indicate an inverse relationship between problem recognition and involvement recognition to intention to join the app.

Table 7

Correlations for the Behavioral Intent to Join the Closed Online Community and STOPS Antecedent Variables

\begin{tabular}{lc}
\hline Variable & $\begin{array}{c}\text { BI: Join Closed Online } \\
\text { Community }\end{array}$ \\
\hline Problem Recognition & $-.29 * *$ \\
Constraint Recognition & $.31^{* *}$ \\
Involvement Recognition & $-.05^{* *}$ \\
Referent Criterion & $.32^{* *}$ \\
\hline
\end{tabular}

Note: ${ }^{* *} p<.01$.

Multiple regression was calculated to predict behavioral intention to join the closed online community based on the STOPS antecedent variables. The authors found that STOPS variables account for $14 \%$ of the behavioral intention to join the Schools App, $F(4,497)=20.87$, $p<.001$. Constraint recognition $\beta=.16(p<.01)$ and referent criterion $\beta=.17(p<.01)$ were the most influential variables, while problem recognition $\beta=-.15(p<.01)$ showed an inverse relationship. Table 8 provides unstandardized and standardized beta weights for all variables. 
Table 8

Multiple Regression of STOPS Variables Predicting the Behavioral Intent to Join the Schools App

\begin{tabular}{|l|l|l|l|}
\hline \multicolumn{4}{|l|}{ BI: Join Schools App } \\
\hline Variable & B & SE B & $\beta$ \\
\hline Constant & 3.84 & .21 & \\
\hline Problem Recognition & -.08 & .28 & $-.15^{* *}$ \\
\hline Constraint Recognition & .10 & .32 & $.16^{* *}$ \\
\hline Involvement Recognition & .00 & .03 & $.00^{* *}$ \\
\hline Referent Criterion & .11 & .03 & $.17^{* *}$ \\
\hline$R^{2}$ & .14 & & \\
\hline Adjusted $R^{2}$ & .14 & & \\
\hline$F$ & $20.87^{*}$ & & \\
\hline
\end{tabular}

Note: ${ }^{*} p<001 ; * * p<01$.

Situational motivation in problem solving and referent criterion in relation to communicative action variables

According to STOPS research, situational motivation in problem solving (a summative measure of STOPS antecedents) and referent criterion have a positive relationship with communicative behaviors. The authors computed correlations for each of the six communicative action variables in relation to the STOPS variables for RH 2-7. Information forwarding showed the strongest correlation with situational motivation in problem solving $r=.19(\mathrm{p}<.01)$, which constitutes a small to medium effect size. All communicative action variables demonstrated at least a small to medium correlation with referent criterion, with several higher effect sizes. The largest correlation was information permitting $r=.95(\mathrm{p}<.01)$. In general, most correlations were statistically significant and showed positive relationships with the two STOPS variables which partially supports RH 2-7. 
Table 9

Correlations for Situational Motivation in Problem Solving and Referent Criterion related to Communicative Action Variables

\begin{tabular}{lcc}
\hline Variable & $\begin{array}{c}\text { Situational Motivation in } \\
\text { Problem Solving }\end{array}$ & Referent Criterion \\
\hline Information Seeking & $.11^{*}$ & $.11^{*}$ \\
Information Attending & $.11^{*}$ & $.19^{* *}$ \\
Information Forefending & .01 & $.24^{* *}$ \\
Information Permitting & $.09^{*}$ & $.95^{*}$ \\
Information Forwarding & $.19^{* *}$ & $.19^{* *}$ \\
Information Sharing & $.10^{* *}$ & $.15^{* *}$ \\
\hline Note: ${ }^{* *} p<.01 ; * \mathrm{p}<.05$. & &
\end{tabular}

The authors also used multiple regression to predict communicative action variables in relation to STOPS. As seen in Table 10, all models were statistically significant. Situational motivation in problem solving and referent criterion accounted for $6 \%$ of the variance for information forefending $F(2,499)=15.81(p<.001)$, the most of any other communicative action variable. In addition, information forefending was most influenced by referent criterion $\beta=.25(p<.001)$. While the influence was stronger than seen elsewhere in the other models for information forefending, referent criterion consistently demonstrated the same or higher influence on communicative actions compared to situational motivation in problem solving. 
Table 10

Multiple Regression of STOPS Variables Predicting the Communicative Action

\begin{tabular}{|c|c|c|c|c|c|c|c|c|c|c|c|c|c|c|c|c|c|c|}
\hline \multirow[b]{2}{*}{ Variable } & \multicolumn{3}{|c|}{$\begin{array}{l}\text { Information } \\
\text { Seeking }\end{array}$} & \multicolumn{3}{|c|}{$\begin{array}{l}\text { Information } \\
\text { Attending }\end{array}$} & \multicolumn{3}{|c|}{$\begin{array}{l}\text { Information } \\
\text { Forefending }\end{array}$} & \multicolumn{3}{|c|}{$\begin{array}{l}\text { Information } \\
\text { Permitting }\end{array}$} & \multicolumn{3}{|c|}{$\begin{array}{l}\text { Information } \\
\text { Forwarding }\end{array}$} & \multicolumn{3}{|c|}{ Information Sharing } \\
\hline & $B$ & $S E B$ & $\beta$ & $B$ & $\begin{array}{l}S E \\
B\end{array}$ & $\beta$ & $B$ & $S E B$ & $\beta$ & $B$ & $S E B$ & $\beta$ & $B$ & $S E B$ & $\beta$ & $B$ & $S E B$ & $\beta$ \\
\hline Constant & 2.83 & .31 & & 3.73 & .18 & & 3.19 & .25 & & 3.98 & .19 & & 2.60 & .33 & & 3.70 & .20 & \\
\hline $\begin{array}{l}\text { Situational } \\
\text { Motivation in } \\
\text { Problem Solving }\end{array}$ & .15 & .05 & $.13^{* *}$ & .10 & .03 & $\begin{array}{l}.14 * \\
*\end{array}$ & .04 & .04 & .05 & .07 & .03 & $\begin{array}{l}.11 * \\
* *\end{array}$ & .07 & .06 & .05 & .09 & .03 & $.13 * *$ \\
\hline Referent Criterion & .13 & .05 & $.13 * *$ & .13 & .03 & $.21^{*}$ & .21 & .03 & $\begin{array}{l}.25 \\
*\end{array}$ & .07 & .03 & $\begin{array}{l}.11 * \\
* *\end{array}$ & .21 & .05 & $.20^{*}$ & .11 & .03 & $.17^{*}$ \\
\hline$R^{2}$ & .03 & & & .06 & & & .06 & & & .02 & & & .04 & & & .04 & & \\
\hline Adjusted $R^{2}$ & .03 & & & .05 & & & .06 & & & .01 & & & .03 & & & .03 & & \\
\hline$F$ & $\begin{array}{l}7.31 \\
* *\end{array}$ & & & $\begin{array}{l}15.04 \\
*\end{array}$ & & & $\begin{array}{l}15.81 \\
*\end{array}$ & & & $\begin{array}{l}5.05 \\
* *\end{array}$ & & & $\begin{array}{l}9.70 \\
*\end{array}$ & & & $\begin{array}{l}9.70 \\
*\end{array}$ & & \\
\hline
\end{tabular}

Note: ${ }^{*} p<.001 ;{ }^{* *} \mathrm{p}<.01 ;{ }^{* * *} \mathrm{p}<.05$ 
Variables and their effect on the behavioral intention of enrolling at a university

RH8 proposes situational motivation in problem solving and referent criteria will be a predictor of a student's likelihood to enroll at the university. As seen in Table 11, the hypothesis is partially supported. Situational motivation in problem solving $r=-.12(\mathrm{p}<.001)$ demonstrated a negative relationship with the behavioral intent to attend the university, while referent criterion $r=.32(\mathrm{p}<.001)$ demonstrated a significant positive relationship. RH9 proposes communicative action variables may also be positively related to the behavioral intention to attend the university. As seen in Table 11, each communicative action variable is positively and significantly related to the behavioral intention to attend the university, which provides support for the hypothesis.

\begin{tabular}{|c|c|}
\hline Variable & BI: Attend the university \\
\hline Situational Motivation in Problem Solving & $-.12 *$ \\
\hline Referent Criterion & $.32 *$ \\
\hline Information Seeking & $.31 *$ \\
\hline Information Attending & $.34 *$ \\
\hline Information Forefending & $.23 *$ \\
\hline Information Permitting & $.30 *$ \\
\hline Information Forwarding & $.31 *$ \\
\hline Information Sharing & $.22 *$ \\
\hline
\end{tabular}

Multiple regression was used to predict the effect of STOPS variables on the behavioral intention to attend the university for RH8. The authors found that the STOPS variables account for $10 \%$ of the respondent's behavioral intention $F(2,499)=29.16(p<.001)$. Referent 
criterion $\beta=.30(p<.001)$ demonstrated a positive medium to large correlation in relation to the respondents' behavioral intention. Multiple regression was also used to predict the communicative action variables in relation to behavioral intention for RH9. The authors found that the communicative action variables predict $17 \%$ of the respondents' behavioral intention $F(6,495)=18.08(p<.001)$. Information attending $\beta=.16(p<.01)$ and information forefending $\beta=.14(p<.01)$ were found to have the largest effect on behavioral intention. Tables 12 and 13 provide unstandardized and standardized beta weights for all variables.

Table 12

Multiple Regression of STOPS Variables Predicting the Behavioral Intention to Attend the University

\begin{tabular}{|l|l|l|l|}
\hline & \multicolumn{3}{|l|}{ BI: Attend the University } \\
\hline Variable & $B$ & SE B & $\beta$ \\
\hline Constant & 3.95 & .18 & \\
\hline $\begin{array}{l}\text { Situational Motivation in Problem } \\
\text { Solving }\end{array}$ & -.05 & .03 & -.07 \\
\hline Referent Criterion & .19 & .03 & $.30^{*}$ \\
\hline$R^{2}$ & .11 & & \\
\hline Adjusted $R^{2}$ & .10 & & \\
\hline$F$ & $29.16^{*}$ & & \\
\hline
\end{tabular}

Note: ${ }^{*} p<.001$ 
Table 13

Multiple Regression of Communicative Action Variables Predicting Behavioral Intention to Attend the University

\begin{tabular}{|l|l|l|l|}
\hline & \multicolumn{3}{l|}{ BI: Attend the University } \\
\hline Variable & $B$ & $S E B$ & $\beta$ \\
\hline Constant & 2.40 & .25 & \\
\hline Information Seeking & .07 & .03 & $.11^{* * *}$ \\
\hline Information Attending & .17 & .05 & $.16^{* *}$ \\
\hline Information Forefending & .03 & .03 & .04 \\
\hline Information Permitting & .10 & .05 & $.10^{* * *}$ \\
\hline Information Forwarding & .08 & .03 & $.14^{* *}$ \\
\hline Information Sharing & .03 & .05 & .03 \\
\hline$R^{2}$ & .19 & & \\
\hline Adjusted $R^{2}$ & .17 & & \\
\hline F & $18.08^{*}$ & & \\
\hline
\end{tabular}

Note: ${ }^{*} p<.001 ; * * \mathrm{p}<.01 ; * * * \mathrm{p}<.05$.

Last, RH10 predicted a positive relationship between a student's likelihood to join an online community and enrolling at the university. The authors performed a Pearson's $r$ correlation test on the two variables and found a significant high correlation, $r=.65(\mathrm{p}<.01)$ constituting a large to very large effect.

\section{Chapter 5: Discussion}

This research examines how prospective college student behavior may be influenced in relation to joining and participating in closed online communities. The discussion will concentrate on the results from a survey sent to students who had already joined a closed online community and participation data associated with their answers. Findings from the survey 
generally support the premise that STOPS variables influence a student's decision to join the app, STOPS variables influence a student's communicative behaviors in the app, and that behavioral intentions may be influenced by communicative behaviors in the app.

\subsection{Practical implications}

Recently, total enrollment and student revenue has become more important to universities across the country as competition and options for students have simultaneously increased (College Board, 2013; Rhodes, 2006). As a result, colleges have scrambled to increase enrollment using more sophisticated marketing and communication strategies, including turning to social media strategies (Ruffalo Noel-Levitz, 2015a; Edmiston, 2008; Kirp, Berman, Holman, $\&$ Roberts, 2003). One of those strategies is the use of digital closed online communities, but in a competitive landscape with limited financial and personnel resources, it is incredibly important for universities to effectively allocate time and effort.

Findings from this study indicate a strong relationship between joining a closed online community and intending to enroll at the university associated with that community. In a competitive marketing landscape, this information is extremely valuable for universities looking to adopt a closed online community as an enrollment strategy. As with many enrollment strategies for large institutions, the impact of adopting a closed online community might not impact every student in the enrollment cycle. However, even a small percentage increase in enrollment is meaningful when considering the broad and often expensive marketing strategies available.

Knowing a relationship exists between joining the app and enrolling is a great first step, but what is happening in the closed online community that may be affecting a student's enrollment decision? The findings show that the communicative action within the closed online 
community is also directly related to a student's behavioral intention to enroll at the university. This is important because it provides a potential framework for practitioners to promote certain types of engagement within their closed online communities. Knowing that information attending and forwarding influence the decision to enroll more than other communicative actions, marketers should design engagement plans to specifically promote those activities. For example, marketers should develop strategies to increase opportunities for students to share information about the university associated with the community and also to receive information from many sources. That being said, all communicative actions were positively correlated with the behavioral intent to enroll so any interaction in the closed online community may be beneficial as a student makes their college decision.

Obviously, with these new findings universities wishing to employ a closed online community would be wise to promote adoption and engagement within the app. However, with limited resources, universities may also want to consider targeting efforts toward students who are more likely to join the app. The findings show that students who do not feel constrained about the decision, do not feel a high attachment to the problem, and have a clear plan to solve the decision are more likely to join the app. Practitioners can interpret this information in two ways: 1) It will be easier to get similar students who are not as stressed about the decision to join the closed online community and enroll as a result, 2) It is important to promote the app more to students who may be less likely to join and are more stressed about the decision because they could benefit from the communicative behaviors within the app. Using this information, universities can develop marketing strategies to communicate the benefits of the closed online community to their target audience to boost adoption and, as a result, enrollment. Additional 
research may be needed to help develop a framework to identify and communicate to these students.

\subsection{Theoretical implications}

In addition to providing actionable items for practitioners to use when developing strategies related to closed online communities as enrollment tools, the research also helps increase theoretical understanding related to STOPS, communicative action, and behavioral intention. First, this research pushes the literature into a new context. Choosing a university can be an incredibly complex, long, and personal decision for students. The impacts of choosing a university will not only affect the immediate years following the decision, but also the remainder of one's life. While previous STOPS research has focused on serious decisions, many of the decisions were activism-based and potentially did not carry the same emotional weight as choosing a university. As a result, the decision-making processes related to choosing a university are undoubtedly different than those previously tested, and pushed the existing scales into uncharted territory. Expanding the literature in this direction provides a solid foundation for researchers to continue to push the limits of STOPS and related constructs. It may also provide a starting point for researchers to adjust STOPS measures to better fit the context of the decision under investigation. Researchers should explore extending the instrument to accommodate more extreme opinions concerning decision-making. For example, instead of or in addition using a measure such as "I am curious about this decision," researchers might use a measure like "I prioritize learning about this decision above any other decision." In doing so, the instrument may be able to better assess the seriousness of a respondent's decision-making process while still providing room in the instrument for subtlety. 
The research also expanded the concept of relating STOPS variables to behavioral intention. As noted in previous research (Kim, Shen \& Morgan, 2011), there is a possible relationship between STOPS variables and behavioral intention. Not only did the authors retest the approach developed by Kim, Shen \& Morgan (2011), they also moved the concept one step further. In testing the STOPS antecedent variables in addition to situational motivation in problem solving and referent criterion, the authors demonstrated that there might be important differences between variables that eventually lead to action. Specifically, testing the antecedent variables showed that, even though situational motivation in problem solving demonstrates one relationship with behavioral intention, subtleties exist within its antecedents. It will be important to continue to test the relationships to better understand how the antecedents interact with each other in relation to behavior, but this research may serve as a foundation for future investigation.

The authors also investigated how communicative action variables impact behavior, a concept that has not been tested previously. This new research fills a gap in the literature. Findings indicate there is in fact a significant relationship between the two variables. The findings also raise the question of how STOPS and communicative action interact to affect other variables. If communicative action is related to behavioral intention, it may also be related to advocacy, academic success, or student retention. Knowing that STOPS variables lead to communicative action, researchers may find specific and actionable data that could expand theoretical knowledge and help practitioners develop strategies to not only enroll more students, but also enroll the right students.

\subsection{Limitations and Future Research}

As with all academic research, this study has its limitations. First, the demographics of the sample were designed specifically to mirror one university's admitted class. While that does 
provide additional utility for officials at the university in question, the results may be different for a university class with dissimilar demographics. The sample was primarily white and female and, since this is the first stage in a multi-stage study, the sample consisted entirely of students who had joined the online closed community. While the findings are useful in many ways, excluding non-joiners from data analysis raises questions about how joiners and non-joiners differ. Future research should take into consideration a more diverse group of students in order to generalize the findings including different geographic regions, university sizes, student academic achievement levels, and extra attention to how universities are marketed before enrollment.

Second, due to the timing of this research it is impossible to say whether respondents will or will not attend the university. While the measure for behavioral intention is reliable, there are many factors that go into making a college decision and it is not unusual for a student to initially choose a university that they are unable to attend (Ruffalo Noel-Levitz, 2015a). Future research could compare official enrollment records with respondent information to better understand the actual relationship between closed online communities and enrolling at the university, beyond behavioral intention.

Third, future studies should consider providing more opportunities for respondents to provide descriptive answers about their college decision. While we know there are many factors that influence a college decision (e.g., cost, location, academic profiles, etc.), this study did not ask for information from the respondents about which might have been more important than others. Finding trends in what is influencing the college decision and how students are communicating about that decision may shed additional light on where closed online communities fit into the equation. 
Last, future studies should not rely solely on the summative measure of situational motivation in problem solving. While findings were significant and useful with situational motivation, testing antecedent variables in addition to situational motivation demonstrated that there are likely subtleties between STOPS antecedents and dependent variables that may be important for practitioners and researchers alike. Researchers should test both antecedent variables and situational motivation to build a well-rounded data set.

\section{Chapter 6: Conclusions}

From a practical perspective, these findings are important for university officials wishing to explore closed online communities as an enrollment tool. First, they provide solid evidence that joining an online community has a significant relationship to enrolling at the university. With heavy competition between institutions and a variety of tools all claiming to help increase enrollment, it can be difficult for a university to choose the right strategy. These results may help officials make better decisions in the future. Second, they underscore the importance of the communicative experience in the closed online community. Joining the app is an important first step but, without the communication that results, students may not fully benefit from the experience.

The findings also expand academic literature around the Situational Theory in Problem Solving and provide a solid foundation for future research to explore connections between activity in a closed online community and behavior. While connections between STOPS variables and behavioral intention has been established in previous studies, this study went further by testing additional variables in a new context. In doing so, the results show that 
important differences may exist between antecedent variables in relation to behavioral intention. The study also tested STOPS in a new context, further generalizing the theory.

Ultimately, this study provides evidence that universities may benefit from engaging in closed online communities and promoting student participation within them. Universities that encourage participation and engagement in closed online communities may see an increase in enrollment. Practitioners wishing to employ closed online communities can use this data to promote the potential of closed online communities but, more importantly, justify spending time developing strategies around adoption and engagement. 


\section{References}

Aldoory, L., Kim, J. N., \& Tindall, N. (2010). The influence of perceived shared risk in crisis communication: Elaborating the situational theory of publics. Public Relations Review, 36(2), 134-140.

Ajzen, I. (1985). From intentions to actions: A theory of planned behavior. In J. Kuhl, \& J. Beckman (Eds.), Action- control: From cognition to behavior (pp. 11-39). Heidelberg, Germany: Springer.

Ajzen, I. (1991). The theory of planned behavior. Organizational Behavior and Human Decision Processes, 50(2), 179-211. doi:10.1016/0749-5978(91)90020-T

Ajzen, I. (2005). Attitudes, personality, and behavior (2nd ed.). Maidenhead, NY: Open University Press.

Ajzen, I., \& Fishbein, M. (1980). Understanding attitudes and predicting social behaviour. Englewood Cliffs, NJ: Pearson. Armitage, C. J., \& Conner, M. (2001). Efficacy of the theory of planned behaviour: A meta-analytic review. British Journal of Social Psychology, 40, 471-499. doi:10.1348/014466601164939

Cohen, J. (1992). A power primer. Psychological Bulletin, 112(1), 155-159. https://doi.org/10.1037/0033-2909.112.1.155

CollegeBoard (2013). Net Tuition Revenues, Subsidies, and Education Expenditures per Student at Public Institutions over Time. (n.d.). Retrieved September 14, 2016, from https://trends.collegeboard.org/content/net-tuition-revenues-subsidies-and-educationexpenditures-student-public-institutions-over

Constantinides, E., \& Stagno, M. C. Z. (2012). Higher Education Marketing : A study on the impact of social media on study selection and university choice. International Journal of Technology and Education

Duggan, M. (2015). Mobile Messaging and Social Media 2015. Pew Research Center. August 2015. http://www.pewinternet.org/2015/08/19/mobile-messaging-and-social-media-2015/

Edmiston, D. (2008). An examination of integrated marketing communication in US public institutions of higher education. International Journal of Educational Advancement, 8(3-4), 152-175. http://doi.org/10.1057/ijea.2009.1 
Fagioli, L. P., \& Rios-Aguilar, C. (n.d.). Changing the Context of Student Engagement: Using Facebook to Increase Community College Student Persistence and Success, 118(1), 1-64.

Fishbein, M., \& Ajzen, I. (1975). Belief, attitude, intention and behavior: An introduction to theory and research. Reading, MA: Addison-Wesley

Grunig, J. E. (1968). Information, entrepreneurship, and economic development: A study of the decision making processes of Colombian Latifundistas. Unpublished doctoral dissertation, University of Wisconsin.

Grunig, J. E. (1976). Communication behaviors in decision and nondecision situations. Journalism Quarterly, 53, 232-263.

Grunig, J. E. (2003). Constructing public relations theory and practice. In B. Dervin, S. Chaffee, \& L. Foreman-Wenet (Eds.), Communication, another kind of horse race: Essays honoring Richard F. Carter (p. 85-115). Cresskill, NJ: Hampton Press.

Grunig, J. E. (2005). Situational theory of publics. In R. L. Heath (Ed.), Encyclopedia of public relations (p. 778-780). Thousand Oaks, CA: Sage.

Grunig, J. E., \& Hunt, T. (1984). Managing Public Relations. New York: Holt, Rinehart \& Winston.

Hemsley-Brown, J., \& Oplatka, I. (2006). Universities in a competitive global marketplace: A systematic review of the literature on higher education marketing. International Journal of Public Sector Management (Vol. 19). http://doi.org/10.1108/09513550610669176

Kim, J.-N., Grunig, J. E., \& Ni, L. (2010). Reconceptualizing the Communicative Action of Publics: Acquisition, Selection, and Transmission of Information in Problematic Situations. International Journal of Strategic Communication, 4(2), 126-154. http://doi.org/10.1080/15531181003701913

Kim, J.-N. (2006). Communicant Activeness, Cognitive Entrepreneurship, and a Situational Theory of Problem Solving. University of Maryland, College Park. Retrieved from http://drum.lib.umd.edu/bitstream/handle/1903/3710/umi-umd-3527.pdf?sequence=1

Kim, J. N. (2011). Public segmentation using situational theory of problem solving: Illustrating summation method and testing segmented public profiles. Prism, 8(2), 1-12.

Kim, J.N., \& Grunig, J. E. (2011). Problem Solving and Communicative Action: A Situational Theory of Problem Solving. Journal of Communication, 61(1), 120-149. http://doi.org/10.1111/j.1460-2466.2010.01529.x 
Kim, J.N., Ni, L., Kim, S.-H., \& Kim, J. R. (2012). What Makes People Hot? Applying the Situational Theory of Problem Solving to Hot-Issue Publics. Journal of Public Relations Research, 24(2), 144-164. http://doi.org/10.1080/1062726X.2012.626133

Kim, J.N., Shen, H., \& Morgan, S. E. (2011). Information behaviors and problem chain recognition effect: applying situational theory of problem solving in organ donation issues. Health Communication, 26(2), 171-84. http://doi.org/10.1080/10410236.2010.544282

Kim, Y., Miller, A., \& Chon, M. G. (2016). Communicating with Key Publics in Crisis Communication: The Synthetic Approach to the Public Segmentation in CAPS (Communicative Action in Problem Solving). Journal of Contingencies and Crisis Management.

Kirp, D. L., Berman, E. P., Holman, J. T., \& Roberts, P. (2003). Shakespeare, Einstein, and the bottom line: The marketing of higher education (2nd ed.). Cambridge, MA: Harvard University Press.

Lee, H., Oshita, T., Oh, H. J., \& Hove, T. (2014). When Do People Speak Out? Integrating the Spiral of Silence and the Situational Theory of Problem Solving. Journal of Public Relations Research, 26(July 2014), 37-41. http://doi.org/10.1080/1062726X.2013.864243

Martin, C. M. (2015). Social media engagement and collegiate recruitment: An examination of the use of social networks in the college recruitment and student choice processes. (Unpublished doctoral dissertation). Western Kentucky University. doi: http://digitalcommons.wku.edu/diss/93

Mckeever, B. W., Mckeever, R., Holton, A. E., \& Li, J.-Y. (2016). Silent Majority: Childhood Vaccinations and Antecedents to Communicative Action. Mass Communication and Society, (February). http://doi.org/10.1080/15205436.2016.1148172

Mckeever, R., \& Mckeever, B. W. (2011). Prophetic Processes in the Pursuit of reliability: Estimating Alpha for Scales of Unidimensional Latent Constructs. Paper presented at the MAPOR (Midwest Association for Public Opinion Research) Annual Conference, Chicago, IL.

McLeod, J. M., \& Chaffee, S. H. (1973). Interpersonal approaches to communication research. American Behavioral Scientist, 16, 469-500.

National Center for Education Statistics (2014). Projections of Education Projections of Education. Retrieved from https://nces.ed.gov/pubs2014/2014051.pdf 
Ni, L., \& Kim, J.-N. (2009). Classifying publics: Communication behaviors and problemsolving characteristics in controversial issues. International Journal of Strategic Communication, 3, 217-241.

Perrin, A. (2015, October 08). Social Media Usage: 2005-2015. Retrieved September 14, 2016, from http://www.pewinternet.org/2015/10/08/social-networking-usage-2005-2015/

Pressgrove, G. N., \& McKeever, B. W. (2016). Nonprofit relationship management: Extending the organization-public relationship to loyalty and behaviors. Journal of Public Relations Research, 1-19. http://www.tandfonline.com/doi/full/10.1080/1062726X.2016.1233106

Reza, M., Laroche, M., \& Richard, M. (2014). Computers in Human Behavior: The roles of brand community and community engagement in building brand trust on social media. Computers in Human Behavior, 37, 152-161. http://doi.org/10.1016/j.chb.2014.04.016

Rhodes, F.T. (2006). After 40 years of growth and change, higher education faces new challenges. The Chronicle of Higher Education 53 (14): A18.

Ruffalo Noel-Levitz (2015a). 2015 E-Expectations Report, 1-24.

Ruffalo Noel-Levitz (2015b). 2015 High School Students' and Parents' Perceptions of and Preferences for Communication With Colleges.

Ruffalo Noel-Levitz (2015c). Navigating the Student Engagement Stream: The Evolution of the Funnel for Enrollment and Beyond, 1-12. 


\section{Appendix A}

\section{Survey}

Note: Words in italics did not display for participants and, unless noted in parentheses, measures all used a five-point Likert scale. Mention of the university related to the closed online community has been redacted.

\section{Introduction}

Thanks for taking part in this survey! This should take 5-10 minutes of your time and your responses will contain no identifiable information.

We're happy you applied to [the university], but we're also sure there were things we could do better throughout that process. That's why we want to learn more about how you are making your college decision. The findings will help the Office of Admissions improve the communications we send to future admitted students.

This study is being conducted by the [university] Office of Admissions and Evan Moore, a [university] employee and West Virginia University master's student.

\section{Consent}

Before you begin, please read the information below and indicate whether you agree to participate in this study. To thank you for completing the questionnaire, one student will be chosen at random to receive a mailed box with [university] gear.

The research should not put you in any unusual physical or psychological risk. Your participation in this study is voluntary, but we hope you will take part. Your responses will be associated with information you submitted in your application, but all of your responses 
within the context of this study are completely confidential. In fact, we are required by federal government and university rules to protect participants' confidentiality.

If you have questions concerning your rights as a research subject, you should direct them to Dan Vasgird, Director of the WVU Office of Research Integrity and Compliance (304293-6094, Daniel.Vasgird@mail.wvu.edu).

By proceeding you are indicating that you have read this statement and agree to participate in this study. If at any point during the study you determine you do not want to continue, you may stop and your responses will be destroyed.

\section{Questionnaire}

Your decision (intro for STOPS section)

Every student has a decision to make when researching and choosing a university, and yours is undoubtedly different than every other student's. Whenever we use the term "the decision" we're referring to your experiences thinking about different universities. Answer the questions below with your experiences in mind.

\section{Situational Theory of Problem Solving}

Problem Recognition

- I am very concerned about this decision.

- I consider this decision seriously.

- I believe I need to pay more attention to this decision.

- I see a huge gap between where I am and where I want to be with the decision.

\section{Constraint Recognition}

- I am NOT afraid to take action related to this decision.

- I can make difference the way this decision solved.

- I can improve the situation better by taking actions for this decision.

- I find NO obstacles in making this decision. 
- This decision affects my life.

- I think this decision could affect me personally.

- I am connected with this decision and its consequences.

- This decision has serious consequences for my life.

\section{Referent Criterion}

- I know how to deal with this decision.

- I have a clear idea and direction to deal with this decision.

- I have faced a similar decision in the past.

- This decision makes me more emotional than the other decisions I have experienced in the past.

\section{Situational Motivation}

- I am curious about this decision.

- I frequently think about this decision.

- I would like to better understand this decision.

- I often stop and think about this decision.

Joining the Schools App (intro for Behavioral Intention section)

The Schools App is an optional online community for admitted students at [the university]. Answer the questions below with your experiences related to the Schools App in mind.

\section{Behavioral Intention}

Joining the Schools App

- If there was a way to meet other prospective students, I would participate.

- I am likely to take part in social media communities with other prospective students.

- I plan to join the closed online admitted student community at [the university] (the Schools App).

- I am NOT interested in participating in online communities with other prospective students.

- Have you joined the Schools App? (Possible answers: 'Yes,' 'No,' 'I'm not sure')

Your experience using the Schools App (intro for Communicative Action section) 
The Schools App is an optional online community for admitted students at [the university]. Answer the questions below with your experiences related to the Schools App in mind.

\section{Communicative Action}

Information Forefending

- I have invested enough time and energy to inform myself about [the university].

- I know where to go when I need updated information regarding [the university].

Information Permitting

- I want to know about [the university] from multiple sources.

- I welcome any information about [the university].

Information Forwarding

- I enjoy opportunities to educate others with information about [the university].

- I forward information about [the university] to people I know.

\section{Information Sharing}

- I would be willing to talk to someone about [the university] if they asked me.

- I may not initiate but I am willing to have a conversation about [the university].

\section{Information Seeking}

- I search for information about [the university] in the news or online.

- I actively search for information about [the university].

\section{Information Attending}

- If I hear someone talking about [the university], I am likely to listen.

- If I see something about [the university] in the news or online, I am likely to watch/listen/read the story.

\section{Your decision (intro for Behavioral Intention section)}

Although you may still be deciding which university to attend and your answers may change in the future, answer the following questions to the best of your ability.

\section{Behavioral Intention}

Yield

- I intend to enroll at [the university] in the fall. 
- [The university] is one of my top schools.

- I was admitted to universities or institutions other than [the university].

- If there were no limiting factors (e.g., cost, distance, etc.) I would attend [the university] in the fall.

- Did you apply to universities other than [the university]? (Possible answers: 'Yes, ' No,' 'I don't recall')

- If a student answered 'yes,' they were then prompted with the question, "How many other universities or institutions did you apply to?"

- Were you admitted to universities or institutions other than [the university]? (Possible answers: 'Yes,' 'No,' 'I don't recall')

- If a student answered 'yes,' they were then prompted with the question, "How many other universities or institutions were you admitted to?" 